\title{
Article
}

\section{Replaying and Rediscovering The Octoroon}

Merrill, Lisa and Saxon, Theresa

Available at http://clok.uclan.ac.uk/17558/

Merrill, Lisa and Saxon, Theresa ORCID: 0000-0002-2129-2570 (2017)

Replaying and Rediscovering The Octoroon. Theatre Journal, 69 (2). ISSN 0192-2882

It is advisable to refer to the publisher's version if you intend to cite from the work. http://dx.doi.org/10.1353/tj.2017.0021

For more information about UCLan's research in this area go to http://www.uclan.ac.uk/researchgroups/ and search for < name of research Group>.

For information about Research generally at UCLan please go to http://www.uclan.ac.uk/research/

All outputs in CLoK are protected by Intellectual Property Rights law, including Copyright law. Copyright, IPR and Moral Rights for the works on this site are retained by the individual authors and/or other copyright owners. Terms and conditions for use of this material are defined in the policies page.

\section{CLoK}

Central Lancashire online Knowledge www.clok.uclan.ac.uk

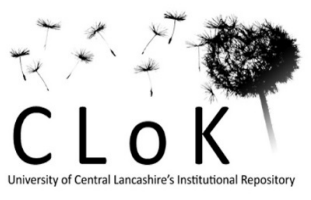




\title{
Replaying and Rediscovering The Octoroon
}

\author{
Lisa Merrill and Theresa Saxon
}

"[W]hen one is considering the crimes of slavery, the popular theater is as central as the courthouse."1

Saidiya Hartman

For over one hundred and fifty years, productions and adaptations of Irish playwright Dion Boucicault's explosive 1859 melodrama, The Octoroon, have reflected differing and sometimes contentious meanings and messages about race and enslavement in a range of geographic locations and historical moments. In this melodrama, set on a plantation in Louisiana, audiences witness the drama of Zoe Peyton, a mixed-race white-appearing heroine who learns after the sudden death of her owner/father, that she is relegated to the condition of "chattel property" belonging to the estate, since she was born of a mother who had herself been enslaved.2 Rather than submit to a new master, having been sold at auction, Zoe poisons herself and dies, graphically, on stage.

The play is famous in the annals of theatre and performance history for reactions to its depiction of slavery in antebellum America and for the various rewrites to which the script was subjected in a Britain that had already abolished the slave trade. In London, in 1861, Boucicault famously rewrote the ending, allowing the heroine to survive and be united with her white lover, in another (presumably more fair) country, ostensibly England. Critical accounts of this adaptation have relied on newspaper reports, as the playscript itself was never published. Within a short time, Boucicault changed the ending again, this time leaving Zoe silent in the arms of her lover, as both witnessed the burning 
of the steamboat Magnolia. This four-act edition was published widely and it and the original American version have formed the basis for most critical assessments of The Octoroon. A key assumption so far has been that this four-act version became an authoritative text for UK productions, and Zoe died no more on British stages. But we have found this is not the case.

Here, we discuss our archival discoveries of Octoroon promptbooks and playbills that reveal previously unknown aspects of the play's stage history and critically illuminate ways the transatlantic theatre of the mid-nineteenth century portrayed enslaved mixed-raced figures and interracial relationships. Although theatre historians have known about Boucicault's original adaptation for over one hundred and fifty years, no extant script for that original "British" version has heretofore been discovered. Now, however, our recent archival discoveries reveal portions of that long-missing script. At the University of Canterbury Kent, we have discovered promptbooks of a later 1871 production of The Octoroon that provide specific textual evidence and blocking details that represent the first amended version as witnessed by London audiences a decade earlier, and described at the time in the London press. In addition, in the same archive, we have uncovered evidence, that we discuss below, establishing that multiple versions of The Octoroon were being staged simultaneously, thereby further de-centering nineteenthcentury perceptions of both mixed- raced bodies and binary definitions of race in the nineteenth century and complicating the received narratives of race and reception regarding this play.

Moreover, in other archives we have found evidence that The Octoroon appeared on the colonial stages of Australia a full ten months before it was staged in London and 
therefore before Boucicault changed the ending. Our exploration of the performance history of The Octoroon in Australia further illustrates the potential shifting meanings of racial categories and representations of enslavement in nations whose colonial histories were built upon differing constructions of racist oppression, genocide, and slavery. Thus, we discuss ways productions of The Octoroon have served as a unique vehicle for depicting the transatlantic and colonial cultural attitudes that surrounded, and tensions that emerged from, antebellum representations of racialization, racial hybridity, interracial desire, and enslavement on both sides of the Atlantic and across British colonies in Australia.

Furthermore, the actors' promptbooks we have located contain several different endings written into the same script. Such promptbooks demonstrate the tensions between archive and repertoire so powerfully articulated by Diana Taylor. 3 Although constructed in the form of printed scripts, these objects were used repeatedly by a number of different actors, and contain notations that both reflect different actors' embodied gestures and blocking, as well as the editorial changes that transformed the printed text. In this way, The Octoroon promptbooks discussed below form a collection of what Taylor terms "scenarios," outlines for performance in a "portable framework" that "bears the weight of accumulative repeats" and so makes visible "the ghosts, the images, the stereotypes" in what are montages of multiple performances.4

From its first staging in New York in 1859, the story of The Octoroon has appeared in many guises, the most recent of which is Branden Jacobs-Jenkins's wholly new 2014 OBIE award-winning play, An Octoroon, which is an inventive retelling of Boucicault's melodrama. In Jacobs-Jenkins's play, Boucicault's narrative is reconfigured 
from the viewpoint of a contemporary black American playwright character who struggles and debates with the character of Dion Boucicault. When Jacobs-Jenkins's An Octoroon debuted in New York in 2014, Tom Sellar wrote, "[w]hen most new American plays rearrange history to tackle social issues, authors tend to give audiences a compass so they're comfortable." But Sellar commended Jacobs-Jenkins for not taking this easy path, noting instead that the playwright forces his characters "to reckon with troubling artifacts on stage," even if they unsettle the audience.5 Although a detailed discussion of Jacobs-Jenkins's powerful play is outside the purview of this essay, we foreground it to establish that the debates raised in The Octoroon and the legacy of its performance history of staging such (intentionally) "unsettling" troubling artifacts make it as relevant today as it was more than a century and a half ago.

In this essay, we examine ways that a range of scenarios of enslavement that were articulated in Boucicault's antebellum melodrama were deployed to serve competing and contradictory ends. We revisit the complex performance history of the play, and of Boucicault's textual changes, and we explore how the body of Boucicault's whiteappearing heroine character was transformed into a figurative artifact to serve complex and contradictory ideologies of race, gender, nation, and colonization.

As Elizabeth Maddock Dillon has prompted of dramatic performances about race in other early Atlantic contexts, we argue that theatrical representations of The Octoroon operated in "arenas of cultural contestation and meaning making that have political force and value."6 Thus, in what follows, informed by our newly discovered material, we interrogate the political values implicit in the multiple endings and the possible meanings spectators' derived from witnessing this play within the contexts of the contrasting legal 
statuses of enslavement, abolition, and colonization that existed in the United States, in Britain, and in Australia.

We begin with an overview of the widely disparate audience reactions to the fate of Zoe Peyton, whose plight (and whose biracial identity) was at the heart of The Octoroon. We move on to explore critical discussions of the American and British versions of the play and the impact on audiences of Boucicault's structural changes to the ending(s). These sections provide crucial context for our archival discoveries. We then discuss those archival discoveries, explaining the significance of the Octoroon promptbooks and playbills we found and the ways they demonstrate a more fluid performance history than critics have so far observed. We then conclude with our discovery and discussion of Australian promptbooks and of the stagings of this play about American slavery in another colonial context, where colonized subjects of color were subjected to race-based genocide. We close with an epilogue exploring the current implications associated with mixed-race characters in Tavia Nyong'o's Amalgamation Waltz 7 and Jacobs-Jenkins's innovative re-configuring of Boucicault's melodrama. Thus, we explain how the material we have uncovered reshapes critical commentary on and replayings of The Octoroon.

\section{Prologue: Setting the Scene}

Nyong'o has observed that images of racial hybridity have been "repeatedly enlisted in envisioning [both] utopian and dystopian scenarios."8 Thus, perhaps it should not surprise us that from the first performance of The Octoroon in New York, in 1859, Boucicault's melodrama and the fate of its mixed-race heroine, elicited complex and 
contradictory responses from audiences, varying from those who criticized or commended the play as either an anti-slavery tract, or one that reinforced the proslavery status quo, either overtly, or by attempting to be "noncommittal" about the horrors of enslavement.

Boucicault's melodrama rested on the fact that although the "white-appearing" Zoe--the eponymous "Octoroon" character--loved and was beloved by her white suitor, because she was juridically considered black, anti-miscegenation laws in Louisiana forbade them from marrying. As Saidiya Hartman has noted, initially Zoe's character was not recognized as black by either the audience or the leading male character within the play, but "Zoe's body becomes legible as a black one by virtue of the violence that threatens it."9 In fact, Zoe transforms her own body into an artifact of racial hybridity when she instructs her white lover to look at her fingernails, and the white of her eyes, to notice "the blueish tinge," which she describes as "the ineffacable curse of Cain," signifying her as one-eighth black, and therefore, "an unclean thing."10 In this way, as Diana Paulin has noted, Zoe's perception of her blackness was embedded in "antiblack public discourse" that was "[r]einforced by eugenics-inspired pseudoscience" that asserted the "innate inferiority" of persons of color.11

Furthermore, once reduced to the state of chattel slavery, audiences witnessed Zoe put on the auction block and purchased by rapacious overseer Jacob M'Closky, who had expressed his designs on her throughout the play. As a result, in the original American version of The Octoroon, Zoe is driven to suicide; her long, agonizing death scene ends the play. According to Paulin, the common role of literary and dramatic mixed-race characters at the time "was that of a tragic figure unable to live in the racially bifurcated 
world."12 Thus, most narratives and plays featuring "tragic mulattas"--white-appearing, exoticized characters, like Zoe--"conclude with such characters unable to survive in the racially divided society, which results in tragic death or exile."13 This was the case depicted in Boucicault's original, American version of the play.

\section{Act I: First New York Production}

The Octoroon opened at a particularly charged time in US and New York City history. Boucicault's biographer, Townsend Walsh, declared The Octoroon the "triumphant success of the year 1859 for Boucicault" since "[t]he slavery question was on everybody's tongue."14 The timing of the New York opening of a melodrama featuring a mixed-race enslaved heroine was both risky and audacious. John Brown's raid on Harper's Ferry had taken place two months earlier on October 16; John Brown was executed for leading that insurrection against slavery on December 2. Pro-South democrat Fernando Wood was elected mayor of New York City on December 6,15 the same day that The Octoroon opened at the Winter Garden Theatre.

Critical reaction to the play was immediate and extreme. For some of Boucicault's white American critics, like the anonymous reviewer from the pro-Democrat New York paper, Spirit of the Times, the prospect of Zoe and George's proposed interracial marriage was exceptionally inflammatory. This paper virulently opposed marriage between a white man and a woman who was legally deemed "black;" this action was considered seditious by its critic, who did not protest the fact of interracial desire--which was the cornerstone of the sexual threat that enslaved black women experienced routinely--but the 
representation on stage of white men who would wish to legitimate that desire with a lawfully sanctioned marriage.16

Indeed, interracial desire was central to The Octoroon's plotting. Biracial heroine Zoe was desired not only by white hero George Peyton, but also by the villainous white overseer M'Closky, whose rapacious aim throughout the play was to possess Zoe as his mistress. The plot turns on M'Closky's manipulation of the slave economy; since by withholding legal papers that would save the bankrupted plantation, he ensured the mixed-race heroine was reduced to chattel property he could "purchase" for such purposes of sexual exploitation. Enslaved women could neither give nor refuse consent, nor offer any resistance to rapacious overtures like that of M'Closky toward Zoe. Boucicault's original production of The Octoroon dramatized this plight, and concluded with Zoe killing herself after overhearing her white lover, George, exclaim that he would rather see her dead than become the property of the overseer. Thus, as Merrill has argued elsewhere, to some extent, responses to The Octoroon rested on spectator and critical reactions to representations of the threat of sexual violence facing enslaved women, as much as to the prospect of interracial marriage. 17

While "mixed-race, destabilizing bodies" in plays like The Octoroon might "appear to be disposed of," as in Zoe's suicide, nonetheless, according to Paulin, they may "still function as surrogates for relationships and desires that undermine the very laws that attempt to police them."18 Thus, given Zoe's mixed-race body, and the interracial marriage to her that George has proposed, paradoxically, The Octoroon could be regarded as either portraying an anti-slavery sentiment in its sympathetic depiction of the sexual horrors confronting enslaved women, forbidden to marry; or the play could be considered 
a pro-slavery tract since Zoe's death left her white lover free to marry Dora, the white Southern woman character who, throughout the play expressed her attraction to George; and was originally unaware of his love for the enslaved Zoe. Thus, Zoe's death paved the way for the ultimate restoration of the white Southern family.Perhaps not surprisingly then, actor Joseph Jefferson III, who played the character Salem Scudder in the original American production, recounted that when the play opened in New York "there were various opinions as to which way the play leaned--whether it was Northern or Southern in its sympathy." Jefferson maintained it "was noncommittal," stating "[t]he dialogue and characters of the play made one feel for the South, but the action proclaimed against slavery, and called loudly for its abolition."19 Agreeing with Jefferson's estimation, the New York Times alleged The Octoroon was not only not explicitly anti-slavery in its sentiment, but declared in a December 15, 1859 review that the play was a "cleverlyconstructed, perfectly impartial, not to say non-committal picture of life as it is in Lousiana.”."20

But the day before performances of The Octoroon even commenced, a New York Herald editorial entitled "Abolition On and Off the Stage" took the opposite position, describing the play as a "work of disunion and treason."21 Denouncing "[t]he rise and progress of the negro-worshipping mania in the United States," the editorial claimed Boucicault's play would be contributing to an "abolition aroma" that included the "sermons of Beecher and Cheever and the novels of Mrs. Stowe."22 In the current climate, the editorial argued, "[n]either a pro-slavery nor an anti-slavery play ought to be performed and a half-way affair is quite as bad, perhaps worse, as it would displease everybody."23 Even if The Octoroon were non-committal, the Herald editor asserted, it 
would "add fuel to the fire which has been increasing slowly but surely these last twenty years." 24 Therefore, even before the play had been staged, the Herald demanded "in the name of the good citizens of the metropolis, that neither that nor any other play of the same character should be performed." 25

Once The Octoroon debuted, other American reviewers voiced decidedly hostile responses as well. The New York Spirit of the Times attributed explicit antislavery sentiments and partisan principles to Boucicault's play, and associated the play and playwright with "the English idea, to endeavour by false sympathy, to break down caste, and elevate the Negro to the same level with the whites."26 Thus, this paper identified Boucicault as English in his beliefs and abolitionist in sentiment: but as an Irish Protestant, with French antecedents, and an English education, Boucicault himself sat on the edge of a complex matrix of identifications.

An article about The Octoroon, published on December 24, 1859 in the New Orleans' Daily Picayune--in the state where the play was set--accused Boucicault of plagiarism, slander, malice, and misrepresentation in depicting the mutually loving relationship between white George Peyton and juridically black Zoe. The Picayune proclaimed that in representing such a relationship, Boucicault had "foresworn his duties as a citizen," and this play had given "a horde of fanatics a dangerous weapon against the general peace."27 As in the Herald editorial, the Picayune's phrasing was prescient: civil war was indeed coming, though Boucicault's play was, overall, an equivocal commentator on the tension before the outbreak of internecine strife rather than a "weapon" inciting a clear pro- or antislavery position. 
Moreover, Boucicault's own position on slavery was unclear and inconsistent, at best. Shortly after the play opened in New York in 1859, Boucicault responded in print to the various criticisms that had been meted out in the press. In a letter to the editor of the New York Herald, Boucicault, who had managed the Gaiety Theatre in New Orleans from December 1855 to March 1856, asserted that the play merely presented, "sketches of slave life, truthful I know, and I hope gentle and kind."28 Boucicault also declared, acerbically, that the Herald's attempt to censor his representation taught him that a "muzzle was the emblem of American freedom and the handcuffs symbols of its liberty."29 Additionally, however, he wrote to the Picayune in January 1860, describing himself as a "Democrat, and a Southern Democrat," and claiming that he would not "mix" himself up with "politics in any way."30

In the first New York production of The Octoroon, Dion Boucicault's Scottish born wife--actress Agnes Robertson--portrayed Zoe, and Boucicault himself elected to portray the Native American "red-faced" character Wah-no-tee.

<INSERT Figure 1><Caption: Figure 1. Boucicault and Robertson.>

At the time, theatrical melodramas about race--like The Octoroon and Uncle Tom's Cabin--generally were performed by all-white casts and drew upon the conventions of blackface minstrelsy when depicting obviously black and Native American characters. Given typical nineteenth-century casting practices, Zoe was generally played by white actresses, as a tragic mixed-race figure not visible as "black."31 Thus, white audiences encountering Robertson's portrayal of "the pretty victim" of Boucicault's melodrama with a light complexion might assume Zoe's similarity to 
themselves, and so decry the arbitrariness of racial categories when considering her plight.32 And yet, such "sympathy," and the colorism and white privilege upon which it was based, rested on an awareness of what Nyong'o has described in another context as "the fictiveness of race--by showing it to be contingent, rather than essential, constructed, rather than a biological given." 33 But given the violence to which enslaved women were subject, regardless of how they appeared, Nyong'o has noted that such an awareness, nevertheless existed alongside "the obscene remainder of racial terror and enjoyment that seems always to survive race's theoretical demolishing." 34

A little-known aspect of the "racial terror" which the earliest productions of The Octoroon stimulated was expressed performatively, with the white starring actress (rather than an actual mixed-race woman) as its target. Almost as soon as The Octoroon opened in New York, both Boucicault and Robertson claimed that Robertson had received death threats for appearing on stage as Zoe and, as a result, decided to withdraw from their contract at the Winter Garden Theatre. 35 In a letter published in the Spirit of the Times, Robertson alleged she had "received letters from many families in this city urging the withdrawal or alteration of the play," and she had been "intimidated by letters threatening us with violence." 36 In portraying Zoe, Robertson claimed that she had been "unconsciously made the instrument to wound the feelings of one part of the public to gratify the other."37 Robertson avowed that she did not want "to make money out of a political excitement--especially on any subject such as slavery, and at such a moment as this. The Octoroon was not intended to succeed on such merits."38

Apparently Robertson's sympathetic portrayal of an enslaved mixed-race woman had fueled the controversy. Years later, Robertson recounted that it was her appearance in 
the slave auction scene that had attracted the most virulent attention. She claimed that she had been "solemnly warned that if I attempted to play this auction scene I should be shot as I stood on the table to be sold." 39 Thus, the threat of actual violence against a racialized and gendered figure on stage, portraying one on the auction platform, was a material fact in both the plot and production history of The Octoroon.

$<$ [INSERT Figure 2, ILN image, Zoe on the table, HERE $><$ Caption: Figure 2. >Citation: Illustration of Zoe's slave auction, in reportage of the London production from Illustrated London News, November 30, 1861, p.562. From Boucicault Collection, Special Collections \& Archives, University of Kent’

Given Hartman's assertion that theatrical performances and staged depictions of blackness had the potential to arouse the contradictory emotions of "pity and fear, desire and revulsion, and terror and pleasure" in an audience at the time, Robertson's sympathetic portrayal of the enslaved and sexually vulnerable mixed-race heroine may well have attracted the menacing attention of hardened pro-slavery activists who threatened her.40 Yet Seldon Faulkner has also suggested that even at the time the production premiered on December 6, 1859, Boucicault wished to break his contract with Winter Garden manager William Stuart and that the playwright and Robertson already were orchestrating a shift to Laura Keene's Theatre. Whatever their motivation, the Boucicaults left the Winter Garden and The Octoroon; although for several months the play continued to be performed there and in several other theatres in New York during the $1859-60$ season. 41 
While Boucicault and Robertson publicly contested the merits of the play in the press, the explicitly sexual threat facing the character, Zoe, roused conflicting emotions in audiences and reviewers. Under slavery, as Hartman has noted, "[t]he rape of black women existed as an unspoken but normative condition fully within the purview of everyday sexual practices." 42 Given the US anti-amalgamation laws that forbade Zoe's marriage to George, it would take Zoe's suicide to free her from the threat of sexual violation by a white "master." But in addition, as Daphne Brooks has contended, Zoe's self-poisoning also could be considered "a gesture having more to do with her aim to ease her lover's pain than to resist M'Closky's advances."43 In any case, Zoe's death served to restore white, Southern patrician status for George, who had, at the slave auction, "lost the 'possession' of his lover to a higher bidder." 44 Whether to reconstruct George's position in a white Southern family, or to enable Zoe to escape the rapacious M'Closky, in the antebellum American world of The Octoroon, only with death would an enslaved woman like Zoe find herself in a position where, as the benevolent white character Scudder articulates, "nary a master to hurt you now." 45

Moreover, at the time of the play's debut in the United States, contentious debates over slavery, over the very humanity of persons of color, and over what constituted "whiteness" or "blackness" were tearing the nation apart. The initial contradictory and violent responses to the play we have discussed above signaled the inevitability of the coming internecine strife. But in Britain slavery had been abolished decades earlier, both by the 1807 Slave Trade Act, which banned the transatlantic traffic in slaves and the 1833 Slavery Abolition Act, which prohibited slavery across the British Empire. British responses to The Octoroon, therefore, were constituted differently, but 
were also framed within fraught and conflicted racialized paradigms, as we explore below.

\section{Act II: The London Rewrite[s]}

On July18, 1860, the Boucicaults returned to England, after a successful run in New York at Laura Keene's Varieties Theater, where they had performed other plays, including Boucicault's hit, The Colleen Bawn.46 In London, Boucicault entered into what would become a contested partnership with Benjamin Webster, manager of London's Theatre Royal New Adelphi, to produce several of his dramas there. In November 1861, almost two years after its New York debut, the Boucicaults staged The Octoroon in London for the first time.47For several weeks the Boucicaults performed The Octoroon as it was staged in America, ending with the character Zoe committing suicide. But London audiences vocally expressed their disapproval at the protracted and graphic death of the heroine. As the London Saturday Review reported on November 21, 1861, the Boucicaults encountered spectators who, "while fully understanding and abhorring the 'domestic institution' [of slavery] do not sufficiently appreciate the prejudice of caste." 48 The Saturday Review explained to its British audience, "[t]he law of Louisiana, that forbids an amiable young gentleman to marry a pretty young woman, merely because there is an infinitesimal drop of black blood in her veins." 49 Thus the periodical differentiated between the English response--incomprehension--and the American "prejudice of caste" which seemed "absurd to an Englishman."50 Letters were written to Boucicault, and published in the British press, imploring him to re-write the ending and allow Zoe to survive and marry her white suitor. 
At first Boucicault resisted, claiming that such a change would reflect a diminution of concern for enslaved women and destroy the artistry of his tragedy. Rather than interpreting the negative audience response as evidence that spectators felt compassion for Zoe's plight, Boucicault suggested in the press that the British public had "grown indifferent to the feelings, and the happiness and purity of black women. The good old days when Uncle Tom made all England cry for pity and shout for the downfall of the accursed bondage of the black, had gone by."51 Instead, England had become "as callous to the sufferings of the Negro, and as indifferent to his rights, as [Simon] Legree himself."52 With his provocative comparison, Boucicault characterized the British public as sharing the point of view of Legree, the evil, plantation overseer character in Stowe's novel. In fact, Boucicault reiterated that "[i]n the death of the Octoroon lies the moral and teaching" of his melodrama.53 He argued, "[h]ad this girl been saved, and the drama brought to a happy end, the horrors of her position, irremediable from the very nature of the institution of slavery, would subside into the condition of a temporary annoyance."54 Sarah Meer has argued that Boucicault's original script, ending with Zoe's death, provides an "index to Boucicault's attitudes on race, interracial marriage, and the nature of plantation society in the Southern United States," all of which, she asserts rested "on the unbridgeability of racial divisions." 55

Nevertheless, Boucicault swiftly adapted the play for London audiences, within weeks producing a version that ended with the promise of George and Zoe united in matrimony, though no marriage is seen to take place on stage. The revised version concluded with a scene in which the audience saw the villainous M'Closky asleep, and Zoe captive, tied to a post with a rope. Then M'Closky, awakened, was chased through a 
scenic red cedar swamp "until he is brought down by a shot from George Peyton ... and the piece concludes with a declaration that in another land Zoe and Peyton will solemnise [sic] a lawful union, and live for the happiness of each other."56

On the premiere of this London adaptation, the December 9, 1861 Adelphi playbill announced:

A New Last Act of the Drama, composed by the Public, and edited by the Author, will be represented on Monday night. He trusts that the audience will accept it as a very grateful tribute to their judgment and taste, which he should be the last to dispute. 57

$<$ INSERT figure 3><Caption: Figure. 3. Adelphi playbill. $>$

However, Meer has claimed that Boucicault's "own views on slavery were less altruistic than his indignant outbursts in The Times suggest," and that Boucicault himself "felt ambivalent about an ending that would free the heroine and marry her to a white hero."58 Yet in acceding to, and authorizing the change in the script's ending, Boucicault, once on British soil, agreed to reverse the prejudice against "amalgamation" that prohibited interracial marriages in the antebellum United States. Moreover, although audiences' expressions of displeasure at the death of the heroine may have prompted Boucicault's revision, by changing the ending the playwright stood to gain financially. In so doing, he could reinvigorate his play, gain publicity for doing so to please his audience, and therefore, draw more paying spectators to see the new version. Thus, Boucicault's attempt to advertise his changed drama by complimenting the previously critical London audience served a particularly pecuniary purpose.59 
But, as Boucicault himself suggested, British playgoers' initial negative responses to Zoe's suicide may, in fact, have demonstrated the limits rather than the depth of their concern for the plight of the enslaved mixed-raced character. In fact, the December 21 issue of the Saturday Review evidenced one of these interpretations when they commended Boucicault's newly changed "happy" ending on the very grounds that The Octoroon was "not a play that appeals to deep feelings, or that is calculated to awake the emotions of highly-wrought pity and tenderness."60 And speaking on behalf of the audience, the Saturday Review claimed it "as a kind of right that we shall not be plunged suddenly and wantonly into the region of pain."61

In either version of The Octoroon, clearly, spectators' responses were complicated and ambiguous. Perhaps, as the Saturday Review claimed, "[t]he audience wished for a happy ending, but they never troubled themselves for a moment about the rights or wrongs of slavery."62 Or their audible disapproving reaction to Zoe's death may have been merely a commentary on the dramatic weakness of the suicide scene, rather than compassion for the enslaved mixed-race woman subject to sexual slavery. In either case, after Boucicault changed the play's ending, the British satiric periodical, Punch, published a thirteen stanza parodic poem, "Saving the Octoroon," that lampooned both the motivation and effect of Boucicault's revision, as they glibly implored:

Say Boucicault, that she survives!

Grant us this public boon;

If cats are blessed with nine-fold lives

Give two to her, this pearl of wives 
Don’t kill the Octoroon! 63

A month later, another Punch article ironically suggested that, since "some playgoers delight in being made extremely miserable, the heroine should try to please both sorts of her admirers by killing herself one night and marrying the next."64 In rendering as equivalent the death or survival of the enslaved heroine character, Punch facetiously demonstrated the ambivalence of some British audiences to viewing the plight of the enslaved woman. Thus, the audience's antipathy to Zoe's suicide was depicted as motivated largely by aesthetic reactions, rather than by political or humane concerns. 65 Hence, whatever it meant for largely white audiences to "delight in being made extremely miserable" by viewing such melodramatic representations of slavery, this same enjoyment appeared to be elicited by responses to both versions of Boucicault's play, whether Zoe lives or dies.

Months earlier, before Boucicault had changed the ending, a critic from the London periodical, John Bull suggested that since,

[t]he British public are practically so unacquainted with a state of society in which a white man is prevented by law from marrying a woman who may have a drop of black blood in her veins ... they cannot be brought to interest themselves in a hero and heroine whose difficulties arise from such a legal impediment, nor can they see with any great amount of sympathy the force of such a sacrifice as a heroine committing suicide in order to put an end to the difficulty. 66 
In this way, as Jennifer Brody has asserted, "[t]he difference between the two versions points to the very different politics of race in the two nations," and therefore "English audiences, who were at a remove from the direct, systematic, and legal divisions of racial conflict, could radically rewrite the octoroon's narrative."67

Boucicault's rewritten ending reinforced a decidedly Anglocentric worldview. In fact, according to Daphne Brooks, Boucicault's rewritten play could be considered "a morality tale ripe for English self-aggrandizement."68 By having Zoe survive, to travel with George to England, where they might ultimately marry, Boucicault's production "dramatized England's moral and cultural superiority to the United States" as a land of liberty, when compared with the slavery present in its former colony.69 While Boucicault's initial dramatization of the death of the juridically black heroine may have caused unease in an England that had abolished slavery decades earlier, stagings of the changed British version of The Octoroon script reinforced and "served as the means by which," according to Brooks, "British culture attempted to reformulate a discourse of moral superiority in relation to its former colonies."70

Britain's status as a "land of liberty" was debatable at this time.71 In 1861, at the dawn of the US Civil War, representations of American slavery on British stages undoubtedly served a range of rhetorical purposes at a moment when Britain was seemingly diminishing its support for the US abolition movement. Many, including Frederick Douglass, had noticed a change in British responses to slavery. A year earlier, in 1860, Douglass attributed the lessening of abolitionist sentiment he witnessed in Britain to the presence there of American "pro-slavery ministers," and to "that pestiferous nuisance, Ethiopian minstrels" who had "brought here the slang phrases, the 
contemptuous sneers, all originating in the spirit of Slavery."72 In these performative exchanges, Douglass claimed, British spectators "had seen the Negro represented in all manner of extravagances, contented and happy as a slave."73 By staging The Octoroon at this time, Boucicault may have been deliberately banking on the charged atmosphere in a Britain at conflict over support for the Union or the Confederate cause. As Brooks has noted, while melodramas were "quite good at meting out racial distinctions, yoking blackness with suffering, and linking moral and racial legibility to a poetics of pain," this play "was less certain about what to do with Zoe's body of excess" which Brooks has called "a transatlantic body in flux."74

As we have discovered, The Octoroon was a transatlantic play in flux, and a further set of amendments to Boucicault's British version occurred by February 1862, when the play was printed in a form that conflated it to four acts with Zoe's presence relegated further to the background. At the conclusion of the printed four-act version, Zoe merely appeared silently, held in George's arms, in a concluding spectacular tableau.75 In fact, as Paulin has noted, even the revised version(s) of the play where Zoe survived still consigned Zoe's body "to some other locale beyond the boundaries of the stage, the plot, the community, and even the nation in which the play is performed."76

Given this production history, Boucicault's play, in its various incarnations, serves as a unique window into theatrical and popular cultural depictions of slavery in the US and Britain both at the particularly charged time in which it debuted in each continent, and subsequently. This is further made manifest when considered in light of the new archival material we have discovered. 


\section{Act III: Our Archival Discoveries, New Old Versions and Promptbooks}

At the University of Kent, in Canterbury, England, we have discovered an Octoroon promptbook belonging to Frederick Wilton, an actor and stage manager of the Britannia Theatre in London's East End from 1846 to 1875.77 Wilton performed the role of Salem Scudder in an 1871 production of the play.78 This promptbook reveals some of the lost details of Boucicault's first set of changes to the ending of The Octoroon in England.

Wilton's promptbook is playfully inscribed, "F. Wilton hys boke July 5 1871," and it consists of Lacy's printed four-act script of The Octoroon, (in which the heroine neither kills herself, nor marries her white suitor, George, but appears silently in his arms in a concluding tableau), into which numerous pages of handwritten annotations are added.79 As we noted above, in this printed four-act version, the printed pages of the script conclude with stage directions that merely state that "George enters, bearing Zoe in his arms--all the characters rush on." Characters watch as the steamboat Magnolia explodes onstage, along with this spectacular stage effect, they form a "grand tableaux," that is followed by the "Curtain."80 The stage directions here do not specify whether Zoe is alive or dead, but in this version there is no suicide scene, so audiences may assume Zoe was rescued by her lover, in whose arms she appears. 81

However, Wilton's promptbook contains additional pages after the four-act script, and includes handwritten notations inscribed in at least two obviously different hands that, along with the printed script, account for three or four different possible endings. Inscribed in ink on pages 6-7 is the notation "Time, first night, own benefit, July 5, 1871, 
Act 1 began 9:30 . . Act 4 ended 11:57 total 2h. 27m."82 According to the notes written onto the otherwise final blank pages, this version of The Octoroon concluded when George rushed onto the boat where M'Closky has taken Zoe. Crossing to center stage, George attacked M'Closky while proclaiming "His life or mine! Zoe once in my arms, I'll bear her away to England where there is but one blood--that which beats in the hearts of honest men \& loving women."83 This line echoes, almost exactly, the published reports from both the Saturday Review and the Illustrated London News, of Boucicault's "new" British ending performed a decade earlier.

According to the Saturday Review's account of Boucicault's original "rewritten" British version in December 1861, Zoe "escape[d] to a land where an eighth part of black blood is not an insuperable bar to marriage."84 As the Illustrated London News reported in their December 14, 1861 review, "[t]he fair Octoroon is thus set at liberty, and the piece concludes with a declaration that in another land Zoe and Peyton will solemnise [sic] a lawful union, and live for the happiness of each other." 85 Thus, although a published version of the script that Boucicault claimed to be written-by-the-audience does not appear to be extant, and, in fact, was never entered by the Lord Chamberlain, in the Wilton "Scudder" promptbook we have located lines that closely resemble the critical accounts of that production.

$<$ INSERT figure 4><Caption: Scudder promptbook.>

On subsequent pages in this same promptbook, a copy of Act V of the original New York version of the play, in which Zoe dies is written in an entirely different handwriting. We have identified the second owner of this promptbook as Sarah Lane, 
manager of the Britannia, and widow of owner Samuel Lane. Another of the Britannia theatre "sides"--the script for The Octoroon character "Pete"--bears the inscription, "Mrs. Sarah Lane, Britannia Theatre, Hoxton, July 6 1871," indicating that Lane played the young black boy Pete (generally a breeches part) in the 1871 production.86 The similarity of this and the second handwriting on the "Scudder" promptbook, lead us to conjecture that Wilton's promptbook became property of Britannia manager Sarah Lane, and passed into her hands for a subsequent reinstated five-act production of the play, in which, once again, the character Zoe dies.

Written into this version is the final scene where Scudder brings water to the poisoned and dying Zoe, who speaks the exact lines uttered in the last act of Boucicault's original American version: "Zoe: lift me so--let me look on him, that his face may be the last I see of this world. Oh! George you may without a blush own your love for the Octoroon."87 Significantly, therefore, we have located evidence of British companies continuing to perform the version of the play culminating with Zoe's death, even after Boucicault changed the ending. In fact, in extant British playbills we have found evidence of productions of three, four, and five-act versions of The Octoroon that described what occurred in each scene of a given production. 88

But we also found that it wasn't only the finale--whether with the mixed-race character's death or survival and (offstage) marriage--that drew spectators to British productions of The Octoroon. Extant playbills from a wide range of different nineteenthcentury productions also establish that sensational scenes and melodramatic spectacles drew audiences to the theatre, as well as did the drama of slavery they saw enacted there. The playbills we examined at the University of Kent and elsewhere listed and described 
all of the scenes in each production, and often included the names of the scenery painters for each set, thereby indicating not only which versions of the play were being staged, but also attesting to the importance of the visual spectacle of Boucicault's melodrama. Brooks has argued that Boucicault's deployment of spectacular sensation scenes (particularly in the English rewritten version of this play), was "very much bound up in exoticizing as well as eroticizing the American 'scene' of slavery." 89 The playbills we have found suggest British spectators responded to the thrilling views of American scenery with the same scopophilic responses as they did to the liminal body of the mixed-race enslaved Zoe, both of which were metonymic for a distant culture of enslavement.

A playbill from Royal Queen's Theatre and Opera House Edinburgh, February 26 and 27, 1862, just months after the London premier of Boucicault's "rewritten" version where Zoe survives, announced "[t]he great sensation drama in five acts entitled the Octoroon."90 This playbill features an account of a purported "true story" of a Miss Winchester who, like the fictional Zoe, was described as "the natural child of the planter by a quadroon slave; she was inventoried in chattels of the estate and sold; the next day her body was found floating in the Ohio river." The playbill declared, "[s]uch is the truth which underlies the story of the Octoroon."91 Presumably, the production of The Octoroon advertised in this manner would feature a mixed-race heroine who commits suicide but the scenes listed on the same playbill also include the duel that Boucicault introduced in the final act in the version in which Zoe survived. Our finding that elements from both US and British versions of the play were contained within the same playbills and promptbooks complicates previous critics' assumptions that disparate versions of The 
Octoroon produced in each locale participated in debates about race and slavery by highlighting "the very different politics of race in the two nations."92

Our discoveries and close readings of the promptbooks, which reveal the simultaneous stagings of both endings subsequent to Boucicault's rewriting, underpin our claims that the montage of artifacts that constitute actors' promptbooks function like scrapbooks, rendering them fluid "scenarios" (in Taylor's sense) of paradoxical and shifting cultural attitudes about race in a given performance venue and spatial locale, rather than functioning as stable textual artifacts.

Finding multiple endings suggests that Britain was caught in a complex and indeterminate web of attitudes about racial identities, and there may have been an awareness on the part of some theatrical producers and spectators that slave labor was not considered as distant and unrelated to the British notions of liberty and justice as the revised "happy endings" for enslaved persons would imply. In fact, we argue that our archival findings reflect the very mixed messages about race and empire, desire and hybridity that were then operative in the metropole. As the Civil War raged in the US and in the years that followed, while various versions of The Octoroon were being staged concurrently, questions of whether any version of this drama advocated the abolition or the proslavery cause continued to fuel uncertainty and fill theatres. However the play ended in Britain and America, The Octoroon complicated notions of racial binaries and spectator sympathy.

In addition, by 1861, given expanding British colonial interests in Africa and Australia, the former colony of America was not the only source for or setting of 
dramatic racialized images in popular culture.93 During and after the Civil War, responses to The Octoroon were caught in an intrinsically complex matrix of global, and diasporic racialized images, as a wide range of competing representations associating blackness with enslavement were in circulation concurrently. Thus, as we explore further below, in the 1860 s and subsequent decades of the nineteenth century, Zoe's white-appearing blackness challenged and exposed the fragility of the race-based colonial narratives upon which British identity was culturally formulated.

\section{Act V: Staging The Octoroon in Australia}

Significantly, we have found that The Octoroon was performed on the colonial stages of Australia a full ten months before it was staged in London. The performance history of The Octoroon in Australia further illustrates the shifting meanings of racial categories and enslavement in other areas of the British Empire as well as the metropole. As Gregory Smithers has argued, "the United States and colonial Australia shared intellectual, economic, and political connections with Britain and each other during the 19th century."94 The three nations also shared a history of racialization, based, in part, on the skewed racist premises of pseudo-sciences such as ethnology. Smithers noted that in his 1813 treatise, Researches into the Physical History of Man, ethnologist James Cowles Pritchard claimed that the "Negro race" included "not only the natives of Africa, but tribes of savages who inhabit New Guinea, New Holland, and many islands in the Pacific Ocean," asserting that "all these nations resemble in many points of their physical structure the genuine Ethiopians."95 Pritchard's ethnological text constructed a racist typology to justify "arranging" all persons of color "in the same class," that he considered "savages or absolutely uncivilized people."96 As a result of Pritchard's racializing 
classifications, Smithers noted, "early $19^{\text {th }}$ century white Americans and British Australians viewed African Americans and Australian Aborigines as two branches of an inferior 'Negroid' race."97

In America, racist beliefs led to hundreds of years of enslavement of African captives and their descendants; in Australia, such attitudes resulted more specifically in systematic genocide of the native population--though certainly forms of slavery existed. In 1858, shortly before The Octoroon was written, Australian legislator William Hull asserted to a Select Committee of the Legislative Council of Victoria, that it was "the design of Providence that the inferior races should pass away before the superior races . . . since we have occupied the country, the aborigines must cease to occupy it."98 This was the immediate backdrop for the first Australian performances of The Octoroon.

According to the Melbourne Argus, the first performance of The Octoroon in Australia--advertised as the "[f]irst time in the colonies of Bourcicault's [sic] great sensation play"--was to take place on January 7, 1861, and featured British actress Madame Marie Duret as Zoe.99 Readers of the Melbourne Age were told that The Octoroon was a play of "thrilling interest" in which "the horrors of slavery are vividly brought out."100 Australian audiences were aware of the existence of slavery in the United States, and some apparently disapproved. As a reviewer in the Ballarat Star asserted, The Octoroon "illustrates the old story of the abominations of slavery."101 This review provided a detailed description of the plot, and noted the play culminated in the death of Zoe, as it had in the original American version. Thus, a range of Australian performances, staged immediately before the outbreak of the US Civil War and predating The 
Octoroon's debut in Britain provide a further window into the representations of American slavery on colonial stages.

Duret was most likely the first performer to bring The Octoroon to Australia, followed swiftly by American actor Charles Wheatleigh, and shortly afterwards by Joseph Jefferson. According to Jefferson, his 1862 production of the play met with a "most satisfactory" reception when he performed it at the Princess's Theatre in Melbourne. 102 The Australian public had "already been made tolerably familiar" with The Octoroon at the time of Jefferson's performance, according to the Argus, and the "anticipations of the audience" was "pleasurably realised."103 In addition to commending Jefferson's performance as Scudder and Rosa Dunn as Zoe, this reviewer singled out for commendation actor Mr Ireland's portrayal slave auctioneer Colonel Poindexter "as if he was familiar with the slave-mart, and had wielded the hammer on another stage than that of the Princess's."104

While we do not know definitely how these productions may have supported or challenged white Australian audience's conceptions of race and slavery; of the white actors, however, it is worth noting that, during his tour, Jefferson derogatively described a native group he encountered as "a more miserable lot of human beings I never saw, long, thin legs and arms, big stomachs, huge, fat heads covered with large shocks of unkempt hair."105 Furthermore, according to Jefferson's autobiography, he accepted tacitly the argument that the reason "the aborigines of this country are fast disappearing," was not the result of racially motivated genocide, kidnapping, and forced labor by colonizing whites, but rather was due, he believed, to a tribal tendency to "drown those children that they did not wish to keep."106 
Whatever his own feelings about race, slavery, and the similarities and differences between the conditions faced by enslaved black Americans and Aboriginal Australians, Jefferson's staging of The Octoroon in Australia ended with Zoe's suicide just as it had done in his original Winter Garden production in New York. However, by the time Jefferson performed The Octoroon in Melbourne, the British audience's reactions to Zoe's death and Boucicault's new "rewritten" ending had also become newsworthy in Australia. In a review dated May 31, 1862, just five days after Jefferson premiered the play in Melbourne, the Argus discussed the new ending being staged in London. The anonymous Australian critic asserted that she or he was "not surprised that Mr. Boucicault should have found it necessary to rewrite the fifth act in deference to public opinion," because, as this critic claimed, "nothing can be more unsatisfactory than the original conclusion."107

Yet, it was not necessarily the biracial heroine's painful and protracted death that bothered this reviewer, or the plight of enslaved black women, but Boucicault's implausible construction of the original concluding scene in which Zoe committed suicide by poisoning herself. As the Argus critic reported, the other characters "should have suspected from her agitated manner, and the impressiveness of her adieux, that the composing draught they were assisting to administer was a deadly poison."108 Thus, the ending in the original version, seemed "incomprehensible," and the characters surrounding Zoe perceived as "singularly slow and obtusely stupid."109 Boucicault's aesthetic plot weaknesses, rather than the death of the heroine, seemed to be the cause of the Australian critic's displeasure. 
While the Argus critic expressed disdain for Boucicault's original version of the play, nonetheless, we have discovered from our examination of reviews and two Australian promptbooks of The Octoroon, that throughout 1861 and 1862, it was this original version, ending with Zoe's suicide that was staged across colonial Australia, even though Boucicault had changed the ending for audiences at the metropole's center. Thus, the original American five-act version continued to be played on colonial stages in Australia after it was changed in London.110 One of the promptbooks we examined is recorded as the property of actor Charles Wheatleigh and the other is listed as belonging to actor and stage manager James Stark. Both Australian promptbooks end with the death of the heroine. But in both cases, the fifth act is a hand-written insertion, indicating that at other times and places other versions of the play may have been performed or considered.

In Wheatleigh's promptbook, the final death scene is a direct transcription of the original US five-act version, in which Zoe commits suicide. This addition is written into a printed copy of the five-act play as produced in the United States. Intriguingly, this script should have contained the printed fifth act ending with the death of Zoe. But this final act had been torn out at some point and a hand-written transcription of the exact same act reinserted into the promptbook. Whether this means that the script, detailed as belonging to Wheatleigh, at some point, had been used for a production that concluded differently, we have not been able to determine.

Stark's promptbook was most likely used during his 1868 tour of Australia. It is pasted into a copy of the four-act edition in which Zoe neither died, nor married George, but ended instead with the grand tableau, with Zoe in George's arms as the steamboat exploded.111 The Stark promptbook, like Wheatleigh's, includes a hand-written addition 
of the original Act Five concluding with the death of Zoe. This promptbook also contains a playbill from a Ballarat performance, which lists the sequence of sensational scenes, from the "Plantation of Terrebonne" to the "death of the octoroon girl Zoe."112The promptbooks and reviews we have discovered for Australian productions of The Octoroon provide further evidence that, as in the United States, the play concluded with the death of the enslaved heroine. In addition, many reviews in the Australian newspapers describe The Octoroon as a play having a plot already so familiar to audiences that it did not warrant retelling. Advertisements in Australia throughout the 1860s continued to bill The Octoroon as Boucicault's "great five-act drama." For all of these reasons we conclude that the original United States production was performed throughout Australia. Given the differently-valenced ways race was constructed in Australia, when compared with both the United States and Britain, it is interesting to speculate how white colonial Australian audiences may have responded to the condition of the enslaved "octoroon," and whether mixed-race or native persons were spectators to the play as well.

Paulin has suggested that it was the "indeterminacy of Zoe’s body" that empowered the character to serve as "a surrogate" for "the intersecting racial, gender, and (trans)national ideologies informing the play."113 Transnational ideologies about race inevitably took on a unique valence when transported to Australia, where "the play's representation of slavery as it related to the practices of empire" was, undoubtedly a crucial factor in its reception, although it is not clear whether circumstances facing Zoe were seen as a surrogate for those facing colonized native women of color in Australia.114 Certainly interracial relationships were known to exist in Australia. Gregory Smithers has noted that in 1839, the Reverend Richard Taylor reported that Australian missionaries 
were "surrounded by settlers who live openly in adultery, or with native females, many of whom are children bought at the age of eight years."115 While some missionaries in nineteenth-century Australia openly wrote of their "disgust" for what they saw as the "lascivious traffic between white men and Aboriginal women" it is not clear how they reacted to these children being reduced to property to be "bought" or owned by whites.116 It was in the context of such practices, observations about interracial relationships, and attitudes toward enslavement and genocide, that white Australian audiences experienced The Octoroon--a play about a heroine born in the United States of an enslaved black mother and the white father who "owned" her.

Thus, in the largely white settler-colony of Australia, what Dillon has described as an operative "theatrics of erasure" may have rendered the offstage "scenes of racialized oppression" in their midst "politically unintelligible and thus 'distant"' at the same time they were, nonetheless, materially present on stage, and possibly in the audience as well.117 Perhaps, as Angela Woollacott has argued, white "settlers in Australia understood that their own prosperity and security were linked to the fortunes of the British Empire in other colonies, and directly identified as Britons when imperial interests were attacked."118 Moreover it is interesting to contemplate ways this play about race may have been considered specifically American in its depiction of enslavement of black persons, or regarded as a further illustration of Britain's colonial project? Or might some Australians have seen in this melodrama distinctive ways of reacting to the plight of those colonized native women of color in their midst? Paul Giles has asserted that, in the nineteenth century, "America was often represented in Australia as a potentially threatening and destabilizing influence."119 For the colonial audience of Australia, events 
of The Octoroon may have been seen as the products of a particularly American slaving system and the death of the heroine an inevitable outcome of what the Ballarat Star had referred to as "the abominations of slavery" in that country.120

Perhaps for some spectators in Britain, Zoe's rewritten "happy ending" there served as a resolution of her plight, and a reification of British claims to moral superiority. But in both the United States, where millions of black women still were enslaved at the time of its debut, and in Australia, where the lives and humanity of indigenous women were threatened, the heroine's suicide largely was accepted and applauded as an appropriate, if necessary, conclusion to the melodrama. Moreover, as Brooks has argued, "[w]hile Zoe's fate is briskly settled in each version of The Octoroon, the situation of slavery remains deeply fetishized, sensationalized, and unresolved."121

\section{Epilogue: Transnational and Transhistorical Legacies}

According to Taylor, "[p]erformances, even those with almost purely aesthetic pretensions, move in all sorts of circuits, including national and transnational spaces and economies."122 We have argued that the various suicide or survival conclusions of The Octoroon, and the multiple endings we have found to be staged at the same time, exemplify Taylor's assertion that "[e]very performance enacts a theory, and every theory performs in the public sphere."123 One of the "theories" enacted in the multiple versions of The Octoroon we have chosen to explore, rests on the various meanings spectators derived from responding to the racialized categories that are called into question by Zoe's mixed-race, hybrid body. 
As our archival discoveries have illustrated, the physical presence of Zoe's staged "black" body registered differently in the United States, in Britain, and in Australia, and perceptions and understandings of such mixed-race bodies may have induced the various re-writings or re-stagings of Boucicault's original script that we have identified in the promptbooks. Thus, we have explored what it meant for the reception of this play to consider its staging in each of the three nineteenth-century spatial, temporal, and transnational contexts for which we have located promptbooks; particularly focusing on how mixed-race identities, such as Zoe's, may have signified on stage in each.

Inevitably, throughout the subsequent decades of the nineteenth century, the quotidian sexual violence to which enslaved black women had been and often still were subject (and which, in fact, was the source of the character Zoe's mixed-race birth and white appearance) took on specific and sometimes contradictory meanings whether or not it was replayed onstage in a Britain now further removed from the sites of such enslavement, although itself the source of an economy based upon the violent dehumanization of race slavery and settler colonization. The re-writings, and (re)insertions into the scripts and promptbooks we have located reflected possibilities or understandings of interracial propinquity in settings where the "physical, embodied proximities" of whites with persons of color, was "imbued with [the potential of] desire and violence" that Dillon has noted is "a central aspect of the colonial relation."124

But wherever they were performed, productions of The Octoroon threatened to call into question the very raced categories upon which slavery (whether still extant, or newly abolished) was based. For in whatever context, it was the staged representation of a hybrid, mixed-race woman's body, and the interracial desire (whether mutual, or 
rapacious) that led to the existence of such a "white-appearing" person, who is nonetheless legally considered "black," that was at the heart of what nineteenth-century spectators saw. Therefore, for those spectators for whom such images of amalgamation portended a possible future of equality, what Nyong'o, has called the "antebellum dream of the hybrid future" the very body of a mixed-race person might be regarded as living evidence of that promise.125 And the changed "happy ending" of a marital life together for biracial Zoe and her white lover, George, might presage a future of interracial families and potential mixed-race descendants who might be considered, in Nyong'o's terms, as "harbinger of a [progressive] transracial future."126 Whereas to those who sought to rigidly police and continue to outlaw "miscegenation" as a threat to the bodily integrity of the nation-state or the colonizing project, such a legitimation of interracial desire, signaled a dangerous, dystopic world gone horribly wrong.

But as Nyong'o has asserted in the conclusion to Amalgamation Waltz, [r]acial mixing and hybridity are neither problems for, nor solutions to, the long history of "race" and "racism" but parts of its genealogy. Racisms can emerge, thrive, and transform quite effectively without ever being undone by the magical, privatized powers we invest in interracial intimacy and reproduction.127

As we have found with the wide range of disparate historical reactions to Boucicault's Zoe, neither (interracial) marriage, nor suicide, nor any other individual solution sufficiently addresses the problems of structural racism that Boucicault depicts, and that still exists to this day, any more than does flying off to another (presumably more accepting) land. Rather, we argue--and Branden Jacobs-Jenkins's current play illustrates-- 
the possibility of overcoming racialized binaries and hierarchies can only be advanced by systematic changes that dismantle the imbrications of racism, colonization, and enslavement at the heart of the history of race-based slavery and empire.

It is not surprising that implicit allusions to the prevailing threats facing current black lives in the United States today inform Jacobs-Jenkins's An Octoroon, while also illuminating the historical tensions about race, colorism, and enslavement present in Boucicault's melodrama. In Jacob-Jenkins's play, contemporary audiences are presented with the challenges involved in representing antebellum black lives in Boucicault's play and the meanings of this for contemporary black Americans when a black actor portraying the new character of black playwright "BJJ" discusses this with a white actor playing playwright Dion Boucicault. As the white Boucicault character prepares to portray Native American character, Wah-No-Tee (a part Boucicault actually performed), the white actor applies "redface" in full view of the audience. Then, further enacting the performativity of race, as well as the slipperiness of racialized categories, the black actor playing BJJ applies "whiteface" as he prepares to depict both the white hero character, George, and white villain M'Closky simultaneously. By having one actor play both of these two white male characters, An Octoroon illustrates the uncomfortable similarity between desire to "own," "master," or "marry" the mixed-race heroine, Zoe, and the implicit similarity in both endings.

As we have established, in the original script of The Octoroon, tragic endings for mixed-race female characters like Zoe were "practically a foregone conclusion," and were regarded as the "unavoidable result of race mixing."128 But in his new radical, innovative, complete re-visioning of Boucicault's play, Jacobs-Jenkins has changed the 
ending yet again: now, giving agency and contemporary voice to a chorus of enslaved, visibly black women characters who were reduced to mere bit parts and largely ignored in Boucicault's original play. Although in this version, once again, Zoe, the "tragic mulatta" character dies, she now poisons herself offstage. The final scene of JacobsJenkins's play concludes with a commentary on the play's action by a duo of strong black women characters, who remark, in contemporary dialect, that "Zoe is such a mess" and instead, they focus, not on "Zoe's lightskinned ass" and concern that she "poison herself over some white man," but tell each other that "you need to let her do that and move on," since as the enslaved Minnie remarks, ironically, "I know we slaves and evurthang, but you are not your job."129 Of course, that was and is an impossibility, but Jacobs-Jenkins's biting and sardonic humor in giving figures reduced to slave labor the imagined ability to voice such sentiments, poignantly forces today's audiences to refocus their attention on the material conditions and lives of ordinary black women, rather than on the eponymous "octoroon."

Following our archival discoveries and our resultant exploration of the extensive, unstable, and fluid replayings of this melodrama and the ambivalent "scenarios," which it stimulated, Boucicault's The Octoroon has been and continues to be as powerful a vehicle for eliciting rethinking about colorism, the constructedness of racialized categories, the dynamics of race and desire, and the hegemony of white privilege in the twenty-first century as it was in the nineteenth.

\section{Notes}


1 Saidiya V. Hartman, Scenes of Subjection: Terror, Slavery, and Self-Making in Nineteenth-Century America (New York: Oxford University Press, 1997), 27. 2 In the nineteenth century, many terms were deployed to codify mixed-race identities. "Octoroon" designated a person of one-eighth African descent. Such persons, no matter how "white" they may have appeared, were subject to the prospect of enslavement. 3 Diana Taylor, The Archive and the Repertoire: Performing Cultural Memory in the Americas (Durham, NC: Duke University Press, 2003).

4 Ibid., 28.

5 Tom Sellar, "Pay No Attention to the Man in the Bunny suit: The 2014 OBIE Awards," Village Voice, May 21, 2014, 8, available at http://www.villagevoice.com/arts/pay-noattention-to-the-man-in-the-bunny-suit-7189537.

6 Elizabeth Maddock Dillon, New World Drama: The Performative Commons in the Atlantic World, 1649-1849 (Durham, NC: Duke University Press, 2014), 9.

7 Tavia Nyong'o, The Amalgamation Waltz: Race, Performance, and the Ruses of Memory (Minneapolis: University of Minnesota Press, 2009).

8 Ibid., 175.

9 Hartman, Scenes of Subjection, note on 210.

10 Dion Boucicault, The Octoroon (New York/Boston: Printed not Published, nd), Act II, p.16, held at Patricia D. Klingenstein Library, New York Historical Society. 11 Diana Rebekkah Paulin, Imperfect Unions: Staging Miscegenation in US Drama and Fiction (Minneapolis: University of Minnesota Press, 2012), 5-6.

12 Ibid., 5.

13 Ibid. 
14 Townsend Walsh, The Career of Dion Boucicault (New York: The Dunlap Society, 1915), 63-64.

15 While some New Yorkers supported the abolition of slavery, Wood was so proConfederacy, that during the Civil War he suggested that New York City secede and join the South.

16 Spirit of the Times, December 17, 1859, 359.

17 See Lisa Merrill, "'May She Read Liberty in your Eyes': Beecher, Boucicault and the Representation and Display of Antebellum Women's Racially Indeterminate Bodies," Journal of Dramatic Theory and Criticism 26, no. 2 (2012): 127-44.

18 Paulin, Imperfect Unions, 26.

19 Joseph Jefferson, Autobiography of Joseph Jefferson (New York: Century Co., 1889), 162.

20 "The Octoroon," New York Times, December 15, 1859, 4.

21 [James Gordon Bennett], "Abolition On and Off the Stage," (editorial), New York Herald, December 5, 1859, 6.

22 Ibid.

23 Ibid.

24 Ibid.

25 Ibid.

26 "'The Octoroon': A Disgrace to the North, a Libel on the South," Spirit of the Times, December 17, 1859, 359 (original emphasis).

27 The Times-Picayune, December 24, 1859, 15. 
28 Dion Boucicault, "Letter from the Author of The Octoroon to the Editor of the Herald," New York Herald, December 7, 1859, 5.

29 Ibid.

30 Dion Boucicault, "Letter to the Editor," New Orleans Picayune, Reprinted in New York Times, February 9, 1860, 2. In this open letter to the Picayune, Boucicault included an extract from another piece of personal correspondence, from himself to the Governor of Louisiana, dated January 17, 1860. In this, Boucicault claimed that his play about "life in Louisiana" had been met with audience satisfaction by "many Southern families of distinction" as it was "a picture of plantation life, not the less faithful because drawn by one who feels so warmly towards the sunny South."

31 Evidence exists of a few black actors and actresses playing Zoe Peyton in subsequent early twentieth-century performances and parodies of the play, which are beyond the purview of this essay.

32 This depiction of Agnes Robertson (Boucicault) as Zoe, and "[t]he charming manner in which she is played" was reported in "The Theatres," The Saturday Review of Politics, Literature, Science and Art (London) 12, no. 317 (November 23, 1861), 538-39 (quote on 538).

33 Nyong'o, The Amalgamation Waltz, 173.

34 Ibid.

35 "Law Reports: The 'Octoroon' Case United States District Court Saturday, Dec. 31," New York Times, January 2, 1860, p. 3.; "Law Reports: The Octoroon War, Irrepressible Conflict between the Manager and the Stage Director of the Winter Garden," New York Times, December 26, 1859, 2. 
36 Spirit of the Times, December 24, 1859, 552.

37 Ibid.

38 Ibid.

39 "A Splendid Record: Mrs Dion Boucicault," The Sketch, May 16, 1894, 146.

Furthermore, Robertson acknowledged that while the play had produced "over thirteen hundred dollars for six performances. ... I cannot consent to sell my own self-esteem and the good opinion of my friends at that or any price."

40 Hartman, Scenes of Subjection, 27.

41 Seldon Faulkner, "The 'Octoroon' War," Educational Theatre Journal 15, no. 1 (1963):

33-38, quote on 35. Boucicault took out a copyright on the play December 12 and on January 21, 1860 the play closed at the Winter Garden. Within three days it opened at the New Bowery theatre, under the management of Fox and Lingard. See "Boucicault v. Fox and Lingard, 5 Blatchford (US), Circuit Court, SD New York, 1862, Public Resource, available at https://law.resource.org/pub/us/case/reporter/F.Cas/0003.f.cas/0003.f.cas.0977.2.pdf . The complexities of the copyright debate are currently under exploration by the authors of this paper.

42 Hartman, Scenes of Subjection, 85.

43 Daphne A. Brooks, Bodies in Dissent: Spectacular Performances of Race and Freedom, 1850-1910 (Durham, NC: Duke University Press, 2006), 33.

44 Ibid.

45 Boucicault, The Octoroon, V.iv, 39. 
46 "Passengers Sailed," New York Times, July 20, 1860, 8. Originally The Octoroon was advertised in London as the "American" version of Colleen Bawn. Both Boucicault plays are predicated on love affairs between partners with different racialized and cultural identities. See Elizabeth Butler Cullingford, "National Identities in Performance: The Stage Englishman of Boucicault's Irish Drama," Theatre Journal 49, no. 3 (1997): 287300, reference on 287. It is beyond the purview of this article to examine the connection between Boucicault's Irish plays and The Octoroon. For others who have explored that, see Scott Boltwood who has argued that exploring The Colleen Bawn and The Octoroon in conjunction offers insight into ways the Irish play was predicated on a similar concept of "racial difference." Scott Boltwood, "'The Ineffaceable Curse Of Cain': Race, Miscegenation, and the Victorian Staging Of Irishness," Victorian Literature and Culture 29, no. 2 (2001): 383-96.

47 A three-act handwritten version of The Octoroon was submitted to the Lord Chamberlain for approval in October 1861. See Dion Boucicault, The Octoroon: A Drama in Three Acts, W. B. Donne [copier], Licence sent October 26, 1861 for performances at New Theatre Royal Adelphi, London, in "Lord Chamberlain's Plays," (a register) British Library. 48 "The Theatres," Saturday Review (November 23, 1861), 538.

49 Ibid.

50 Ibid.

51 Dion Boucicault, as reported in "Happy Endings," The Saturday Review of Politics, Literature, Science and Art (London) 12, no. 321 (December 21, 1861): 633-635, quote on 633. 
52 Ibid. 633. Simon Legree, a character from Harriet Beecher Stowe's widely read 1852 novel, Uncle Tom's Cabin, is the overseer responsible for the death of Tom. The novel had been adapted by John Aitken and H. J. Conway and was then being performed to popular appeal throughout Britain. For a discussion of Uncle Tom's Cabin as performed in Britain, see Sarah Meer, Uncle Tom Mania: Slavery, Minstrelsy, and Transatlantic Culture in the 1850s (Athens, GA: University of Georgia Press, 2005).

53 Dion Boucicault, Letter to the Editor, "The Octoroon," The Times (London), November 20, 1861, 5

54 Ibid.

55 Sarah Meer, "Boucicault's Misdirections: Race, Transatlantic Theatre and Social Position in The Octoroon," Atlantic Studies 6, no. 1 (2009): 81-95, quote on 83. Meer bases her interpretation of Boucicault's attitude on a comparison between Boucicault's melodrama and Mayne Reid's 1856 novel, The Quadroon, upon which Boucicault's original play was based. In Reid's novel, a mixed race enslaved heroine, Aurore, marries her white suitor.

56 The Illustrated London News, December 14, 1861Special Collections \& Archives, University of Kent.

57 Octoroon playbill, New Adelphi Theatre, Monday December 9, 1861, special Collections and Archives, University of Kent. 58 Meer, "Boucicault’s Misdirections," 82. 59 Meer argues that "Boucicault was a master showman, famed in his time for shameless self-promotion," in ibid., 82-83. 60 "Happy Endings," Saturday Review (December 21, 1861); 634; emphasis added. 
61 Ibid.

62 Ibid., 633-34.

63 "Saving the Octoroon," Punch: Or the London Charivari, 41 (December 21, 1861):

252

64 "Our Dramatic Correspondent," Punch: Or the London Charivari 41 (January 4, 1862): 251.

65 Ibid.

66 "Theatres and Music," John Bull [London], 137, no. 2 (November 23, 1861): 748.

67 Jennifer DeVere Brody, Impossible Purities: Blackness, Femininity, and Victorian

Culture (Durham, NC: Duke University Press, 1998), 51.

68 Brooks, Bodies in Dissent, 44.

69 Ibid., 45.

70 Ibid., 44.

71 Enkvist, Nils, "The Octoroon and English Opinions of Slavery," American Quarterly 8, no. 2 (1956): 166-170, reference on 169.

72 Northern Daily Express, February 23, 1860, reprinted in "Frederick Douglass and George Thompson on Slavery," The Anti-Slavery Reporter and Aboriginal Friend 8, no. 6 (1860): 125.

73 Ibid.

74 Brooks, Bodies in Dissent, 37; emphasis added.

75 Dion Boucicault. The Octoroon: A Play, in Four Acts, Dicks's London Acting Edition Standard English Plays and Comic Dramas (London: John Dicks House, n.d.), 28. Also, Dion Boucicault, The Octoroon: A Play, in Four Acts, Lacy's Acting Edition (London: T. 
H. Lacy, n.d.), no. 963. Also, Dion Boucicault, The Octoroon: A Play, in Four Acts, French's Acting Editions (London: Samuel French, n.d.), no. 962. This four-act version is the only authorised publication of The Octoroon, and was produced by Lacy, Dicks, and French. 76 Paulin, Imperfect Unions, 18.

77 Unlike the more fashionable Adelphi Theatre, where Boucicault staged his first British versions of The Octoroon in 1861, the Britannia was located in Hoxton, in London's East End and was erected for Samuel Lane in 1858, at the site of the old Britannia Saloon. The Era reported on the opening of the Britannia Theatre, Hoxton, November 14, 1858. 78 "Octoroon: A Collection of Parts," Promptbook at Templeman Library University of Kent. Frederick Charles Wilton (1802-1899) was born December 3, 1802 in Bristol and died September 8, 1889 in Sydney, where he had retired to in 1876. 79 Boucicault, The Octoroon, Lacy's Acting Edition. 80 Ibid., 28. See also, Boucicault, The Octoroon, French's Acting Editions. 81 Boucicault, The Octoroon, Dicks's London Acting Edition Standard English Plays and Comic Dramas, 28; Boucicault, The Octoroon, Lacy's Acting Edition; and Boucicault, The Octoroon, French's Acting Editions.

82 "Octoroon: A Collection of Parts," Promptbook at Templeman Library University of Kent. 83 Ibid. 84 "Happy Endings," Saturday Review: Politics, Literature, Science and Art, 12 (Jul -Dec 1861) 633-635: 633 85 The Illustrated London News, December 14, 1861. 
86 "Octoroon: A Collection of Parts," Promptbook at Templeman Library University of Kent.

87 Dion Boucicault, The Octoroon (New York/Boston: Printed not Published, n.d), 40, held at Patricia D. Klingenstein Library, New York Historical Society. 88 "Octoroon: A Collection of Parts," Promptbook at Templeman Library University of Kent.

89 Brooks, Bodies in Dissent, 47.

90 Octoroon playbill, Royal Queen's Theatre and Opera House Edinburgh, Wednesday and Thursday February 26 and 27, [1862]. Dated according to perpetual calendar. 91 Ibid. The story of "Miss Winchester" is also reprinted in a later playbill from Birmingham December 14, 1865. Special Collections, Templeman Library, University of Kent. 92 Brody, Impossible Purities, 51. 93 In 1861 the New South Wales Government in The Crown Lands Act 1861 opened up the selection of Crown land for the purchase of free white settlers paying a deposit and living on the land for three years, and limited the use of Crown lands by indigenous people. See "European Discovery and the Colonisation of Australia," Australia.gov.au, March 31, 2015, available at http://www.australia.gov.au/about-australia/australianstory/european-discovery-and-colonisation.

94 Gregory D. Smithers, "'Black Gentleman as Good as White': A Comparative Analysis of African American and Australian Aboriginal Political Protests, 1830-1865," The Journal of African American History, 93, no. 3 (2008): 315-36, quote on 316. 
95 James Cowles Pritchard, Researches into the Physical History of Man (London: John and Arthur Arch, 1813), 215.

96 Ibid.

97 Smithers, "'Black Gentleman as Good as White,"' 316.

98 Willian Hull, J. P. Report of Select Committee of the Legislative Council of the

Aborigines, Victoria, Australia; Together with the Proceedings of Committee, Minutes of Evidence, and Appendices. (Ordered by The Council To Be Printed, John Ferres, Government Printer, Melbourne, 1859), 9, available at http://aiatsis.gov.au/sites/default/files/docs/digitised_collections/remove/92768.pdf. Cited in Russell McGregor, Imagined Destinies: Aboriginal Australians and the Doomed Race Theory, 1880-1939 (Melbourne: Melbourne University Press, 1997), 15.

99 "Amusements," Argus, Melbourne, January 5, 1861, 8.

100 "The News of the Day," Age, Melbourne, January 8, 1861, 5.

101 Star, Ballarat, March 6, 1861, 3.

102 Joseph Jefferson, The Autobiography of Joseph Jefferson (New York: Century, 1889), 239.

103 Argus, Melbourne, May 27, 1862, 5.

104 Ibid.

105 Joseph Jefferson, The Autobiography of Joseph Jefferson (New York: Century, 1889), 244.

106 After an aboriginal child was born, Jefferson was told, if it was "of much trouble to the mother, she tosses it into the river." Ibid., 244. 107 Argus, Melbourne, May 31, 1862, 5. 
108 Ibid.

109 Ibid.

110 Dion Boucicault, The Octoroon, Wheatleigh and Stark promptbooks, Billy Rose Theatre Archives, New York Public Library.

111 On November 6, 1868, the Ballarat Star announced the "first performance of the American tragedian James Stark who will personate the role of Salem Scudder." Star, Ballarat, November 6, 1868, 3.

112 Octoroon playbill, Theatre Royal Melbourne, "November 7 and 9 and till Further Notice," pasted into Promptbook at Billy Rose Theatre Archives, New York Public Library.

113 Paulin, Imperfect Unions, 9.

114 Ibid., 8. While Paulin mentions a need to examine "the play's representation of slavery as it related to the practices of empire such as imperial conquests in Africa and India," she does not mention Australia, where we have discovered it to have been staged. 115 Rev Richard Taylor to Rev W. Cooper, February 6, 1839, in British Parliamentary Papers: Colonies, Australia, 34 vols. (Shannon, Ireland 1968), vol. 8, 45-46. Cited in Gregory D. Smithers, "'Pursuits of the Civilized Man': Race and the Meaning of Civilization in the United States and Australia, 1790s-1850s," Journal of World History 20, no. 2 (2009): 245-72, quote on 268.

116 Ibid., 268.

117 Dillon, New World Drama, 8. 118 Angela Woollacott, Settler Society in the Australian Colonies: Self-Government and Imperial Culture (Oxford: Oxford University Press, 2015), 4. 
119 Paul Giles, Antipodean America: Australasia and the Constitution of US Literature (Oxford: Oxford University Press, 2013), 170.

120 Star, Ballarat, March 6, 1861, 3.

121 Brooks, Bodies in Dissent, 46.

122 Taylor, The Archive and the Repertoire, 27.

123 Ibid.

124 Dillon, New World Drama, 59. Dillon has said this of productions of Oronokoo on the eighteenth-century stage in London and in Charleston, but we believe it is applicable to Octoroon productions in the contexts of the US, Australia, and Britain as well. See Ibid., 58.

125 Nyong'o, The Amalgamation Waltz, 174.

126 Ibid., 176.

127 Ibid., 174.

128 Paulin, Imperfect Unions, 6.

129 Branden Jacobs-Jenkins, An Octoroon (New York: Dramatist's Play Service, 2015),

78. 